\title{
IMAGEM TÉCNICA E IMAGEM TURÍSTICA: CONSIDERAÇÕES SOBRE O INSTAGRAM COMO MOTIVADOR PARA O TURISMO
}

\author{
Imagen Técnica y Imagen Turística: consideraciones sobre el Instagram como motivador para el turismo \\ Technical Image and Tourism Image: considerations about Instagram as a motivator for tourism
}

Renan Augusto Moraes Conceição

Universidade Estadual do Paraná (UNESPAR), campus

Apucarana, PR, Brasil

renan.conceicao@hotmail.com
DOI: https://doi.org/10.18472/cvt.20n1.2020.1747 Redalyc: http://www.redalyc.org/articulo.oa? $\mathrm{id}=115462634008$

Recepción: 06 Agosto 2019

Aprobación: 10 Junio 2020

\section{Resumo:}

Com um mercado que atrai investimentos maciços em publicidade, o turismo movimenta cerca de 1 trilhões de dólares ao ano, segundo a Organização Mundial do Turismo. Deste modo, as empresas turísticas investem em publicidade nas mais variadas formas e redes sociais, como o Instagram, são uma forma de propagação dessa publicidade, impulsionando o desejo pela atividade turística. O objetivo desse artigo é caracterizar o Instagram como um propagador de imagens turísticas de caráter técnico, em que o uso de imagens publicitárias para o turismo ocorre de maneira intensiva e intencional. De caráter bibliográfico, pois se fundamenta nas obras de autores como Belting (2007), Flusser (2011, 2013), Sartre (2008) e Wulf (2013); documental e jornalístico, uma vez que analisa material imagético e de veículos como o jornal El Pais; e exploratório, levantando informações sobre o uso de imagens por alguns usuários do Instagram, essa pesquisa tem como resultado a detecção de padrões nas imagens publicitárias veiculadas no Instagram, originando um movo de vida pautado pela publicidade espontânea, tornando os usuários de aplicativos de imagens em agências de publicidade turística ambulante.

PalaVras-chave: Turismo e publicidade, imagem técnica, Instagram .

\section{Abstract:}

With a market that attracts massive investments in advertising, tourism generates about 1 trillion dollars a year, according to World Tourism Organization. In this way, tourism companies invest in advertising in the most varied forms and social networks, such as Instagram, are a way of spreading this advertising, boosting the desire for tourist activity. The objective of this article is to characterize Instagram as a propagator of tourist images of a technical nature, in which the use of advertising images for tourism occurs intensively and intentionally. Of bibliographical character, as it is based on the works of authors such as Belting (2007), Flusser (2011, 2013), Sartre (2008) and Wulf (2013); documentary and journalistic, since it analyzes imagery material and vehicles such as the newspaper El Pais; and exploratory, raising information about the use of images by some Instagram users, this research results in the detection of patterns in the advertising images shown on Instagram, creating a movement of life based on spontaneous advertising, transforming the users of image apps in walking touristic advertising agencies.

KEYWORDS: Tourism and advertising, technical image, Instagram.

\section{ReSUMEN:}

Con un mercado que atrae inversiones masivas en publicidad, el turismo mueve alrededor de 1 billón de dólares al año, según datos de la Organización Mundial del Turismo. De esta forma, las empresas turísticas invierten en publicidad en diversas formas y las redes sociales, como Instagram, son una forma de difundir esta publicidad, aumentando el deseo de actividad turística. El objetivo de este artículo es caracterizar a Instagram como un propagador de imágenes turisticas de carácter técnico, en el que el uso de imágenes publicitarias para el turismo se produce de manera intensiva e intencional. De naturaleza bibliográfica, ya que se basa en los trabajos de autores como Belting (2007), Flusser (2011, 2013), Sartre (2008) y Wulf(2013); documentaly periodístico, ya que analiza material de imágenes y vehiculos como el periódico El País; y exploratorio, recabando información sobre el uso de imágenes por parte de algunos usuarios de Instagram, esta investigación resulta en la detección de patrones en las imágenes publicitarias mostradas en Instagram, creando un movimiento de vida basado en publicidad espontánea, haciendo los usuarios de aplicaciones de imágenes en agencias de publicidad turistica callejera.

Palabras Clave: Turismo y publicidad, imagen técnica, Instagram.. 


\section{INTRODUÇÃO}

Os estudos em turismo se caracterizam pela predominância de teorias e análises focadas em seus aspectos desenvolvimentistas com abordagem funcionalista e pouco aprofundamento crítico (Ouriques, 2005; Siqueira, 2005). O turismo, atualmente, se configura como uma atividade que abrange todos os continentes e movimenta recursos da ordem de trilhões de dólares ao ano, colocando em movimento 1.2 bilhão de pessoas (United Nations World Tourism Organization [UNWTO], 2018), gerando uma intrincada rede de relações econômicas e sociais que devem ser entendidas em toda a sua amplitude. Realizar a crítica da atividade turística contribui para o aprofundamento da compreensão que esse fenômeno apresenta, sendo necessário um enfoque aos temas que se relacionam com o turismo, direta ou indiretamente. Assim, por ser uma atividade que utiliza muitas imagens por parte da publicidade, realizar a junção entre as teorias da imagem, provenientes do campo da comunicação, e o turismo mostra-se imprescindível. Mesmo que o enfoque na publicidade pareça indicar uma discussão mercadológica, é o tema da imagem técnica que será abordado nesse trabalho.

De caráter bibliográfico, documental e exploratório, uma vez que realiza um levantamento teórico sobre imagem técnica e analisa fotografias, veiculadas por redes sociais, o objetivo desse estudo é caracterizar o aplicativo de imagens Instagram como um propagador de imagens turísticas de caráter técnico, expondo elementos que auxiliem no entendimento do conceito de imagem na atualidade. Para isso, recorre-se aos estudos de autores do campo da comunicação e das teorias da imagem como Vilém Flusser, Christoph Wulfe Hans Belting, que apresentam discussões filosóficas e antropológicas a respeito das imagens. Faz-se necessário salientar que o tema da imagem é estudado na área do turismo, porém, a abordagem é, majoritariamente, concernente ao campo do marketing, tratando da imagem como uma ideia ampla e permeada de estereótipos que caracterizam determinados destinos turísticos. Desse modo, realizar um estudo que relaciona a atividade turística com os estudos de teoria em imagem pode fornecer material primordial para analisar a escalada do poder das imagens e apontar para a antecipação de consequências que o uso indiscriminado de imagens técnicas pode gerar em um futuro breve.

\section{Imagens Como Vetores para o Turismo}

O turismo, enquanto atividade econômica e mercadoria, se utiliza de imagens principalmente no que se refere ao uso por parte da publicidade. Essas imagens narram acontecimentos, formam representações variadas e fazem parte de um discurso e de uma construção histórica. A imagem torna-se o centro de toda a publicidade veiculada, elevada à potência de espetáculo.

Como as imagens turísticas são utilizadas dentro de um discurso amplo, elas transmitem informações a respeito de uma localidade, recheadas de significados subjetivos, formando uma ideia geral que pode se transformar, facilmente, em uma visão estereotipada das sociedades. Essas imagens fazem parte de um processo de dominação do visual, da estética das localidades e das culturas como determinantes no processo turístico - a imagem turística é um fim em si mesma. De acordo com Gumbrecht (2015), muitas pessoas, instigadas pelas imagens vistas no conforto de seus lares, viajam para fazer centenas de fotos que emulam aquela imagem vista em casa, mas inferiores em qualidade. Mesmo com o uso indiscriminado das imagens, o seu estudo em turismo é um campo pouco explorado, pois, segundo Ouriques (2005), Siqueira (2005) e Jafari (1994), os estudos em turismo se concentram nos aspectos culturais, administrativos, mercadológicos e ecológicos da atividade.

Embora, muito se pesquise a respeito da imagem no turismo, salienta-se que as abordagens colocam em foco a imagem do destino com caráter mais voltado ao marketing turístico. É nesse sentido que Bignami (2002), em obra primordial, no estudo da imagem no turismo no Brasil, volta suas considerações à imagem de mercado do produto turístico. A autora ressoa os estudos pioneiros de Hunt $(1971,1975)$ a respeito 
do impacto das imagens dos destinos no processo de decisão do consumidor. Outro estudo pioneiro foi realizado por Gunn (1972), que buscou identificar os fatores que influenciam na formação da imagem de um destino turístico. Todo o desenvolvimento de pesquisas em imagem e turismo é exposto por Costa (2015), em extenso levantamento, deixando evidenciado o fato de que os estudos da imagem em turismo se concentram em algumas abordagens: "[...] os estudos continuam concentrados em torno da definição, do processo de formação e da metodologia de investigação" (Costa, 2015, p. 75). As abordagens que privilegiam a definição de imagem, o processo de formação de imagem e a metodologia de investigação, utilizando imagens, são as vertentes que apresentam maior produção científica. Entretanto, conforme expõe Costa (2015), abordagens centradas em teoria da imagem advinda do campo da comunicação e da antropologia da imagem são menos comuns. É nesse espaço que o presente artigo busca se inserir.

O conceito de imagem pode ser diverso de acordo com o foco de estudo. Sartre (2008) busca analisar como o conceito de imagem apresenta grandes problemas, se diminuído a apenas um aspecto teórico, e sugere formas para uma superação dos problemas da imagem. De forma resumida, Sartre expõe que:

"A teoria pura e a priori fez da imagem uma coisa. Mas a intuição interna nos ensina que a imagem não é a coisa. Esses dados da intuição vão se incorporar à construção teórica sob uma nova forma: a imagem é uma coisa, tanto quanto a coisa da qual é a imagem. Contudo, pelo fato mesmo de ser imagem, recebe uma inferioridade metafísica em relação à coisa que ela representa. Em suma, a imagem é uma coisa menor. A ontologia da imagem está agora completa e sistematizada: a imagem é uma coisa menor, que tem sua existência própria, que se dá à consciência como qualquer outra coisa da qual é imagem” (Sartre, 2008, p. 10).

$\mathrm{O}$ autor enfatiza que, ontologicamente, entende-se a imagem como algo menor do que a coisa a qual ela representa e essa seria uma teoria a priori. Aceitar a imagem como uma coisa traz, desta forma, uma série de desdobramentos no que se refere ao entendimento das imagens no pensamento dos seres humanos. Sartre (2008) explica que o entendimento de imagem apresenta uma estrutura de coisa e o que muda, de acordo com o ângulo de estudo, é a relação da imagem com o pensamento. Na conclusão de seu trabalho sobre a imagem, afirma que "essa afirmação está em relação de plena conveniência com os dados da reflexão. Infelizmente, ela tira sua origem de ideias a priori: ela convém aos dados do senso íntimo, mas não provém deles [grifos do autor]" (Sartre, 2008, p. 136).

Entender a imagem como uma coisa e uma coisa menor, em relação à coisa representada, fornece um entendimento que é conveniente e não a um conhecimento material. Sartre continua: "não há, não poderia haver imagens na consciência. Mas a imagem é um certo tipo de consciência [grifos do autor]. A imagem é um ato e não uma coisa. A imagem é consciência de alguma coisa" (Sartre, 2008, p. 137). Com isso, fica claro que não se pode pensar a imagem apenas como um objeto externo que causa uma impressão na consciência, pois isso seria aceitar uma teoria pura pensada na conveniência de se adequar o entendimento de imagem a um discurso científico. Considerar a imagem, mais do que apenas um objeto menor, traz consequências teóricas fenomenológicas diversas que não entrarão em foco aqui, bastando a esse trabalho entender que o problema da imagem é justamente apresentar características que fogem de conceituações fornecidas por muitas correntes teóricas e que, portanto, é preciso integrar a análise da imagem com vários campos científicos.

Para Flusser (2011, p.15), “imagens são superfícies que pretendem representar algo. Na maioria dos casos, algo que se encontra lá fora no espaço e no tempo”. Apresentado mais elementos, Belting (2007, p. 14) afirma que "los hombres y las mujeres aislan dentro de su actividad visual, que estabelece loslineamientos de la vida, aquella unidas simbólica a la que llamamos imagen "2] ". Assim, a imagem é um componente simbólico da visualidade, em uma superfície que transporta uma mensagem. Embora, Flusser (2011) coloque em evidência que a imagem representa algo que, na maioria das vezes, se encontra fora do observador da imagem, o conceito abarca, também, o que ocorre no subjetivo do observador. Belting (2007) considera que as imagens são resultantes de uma simbolização pessoal e coletiva, considerando como imagem até mesmo as representações 
mentais que não correspondem a um fenômeno no mundo real. Demonstra-se, com isso, a abrangência que o termo pode desenvolver. As ideias são imagens não exteriorizadas, ainda sem um meio de transmissão.

Para que essas ideias e conceitos atravessem essa barreira, outro aspecto deve ser abordado tal como aponta Wulf (2013): as imagens são resultantes de uma faculdade fundamental para o desenvolvimento humano: a imaginação. Para o autor, imaginação é um poder que faz o mundo aparecer aos humanos, é uma força que transforma o mundo interior em exterior. "[...] 'fazer aparecer' significa conceber o mundo através de imagens mentais e criá-lo em conformidade formal” (Wulf, 2013, p. 22). Flusser (2011, p. 15) caracteriza a imaginação como a "capacidade de fazer e decifrar imagens". Assim, conceber uma ideia, criar uma imagem mental e transpor essa ideia para um meio, para uma superfície, concretizando a ideia em imagem, é o que se pode entender por imaginação. Ser capaz de perceber e decifrar o que uma imagem disposta em um meio significa, também, faz parte do processo de imaginação. Como a imagem é representação de algo, Wulf(2013) afirma que o que se vê é uma relação com algo exterior. A imagem faz referência a algo ausente dela, evocando a presença desse elemento representado. Nesse aspecto, Belting (2007) considera que os meios em que as imagens se encontram são como os lados de uma moeda, inseparáveis, porém com significados diferentes. É através dos meios que uma imagem evoca a presença de algo ausente. As imagens turísticas funcionam dentro dessa lógica, elas evocam a presença de um lugar em que o observador não se encontra, elas trazem em si uma presença geográfica.

Assim, as imagens representam o mundo e, segundo Flusser (2011), servem de mapas para guiar o olhar humano pelos fenômenos concretos. Entretanto, o autor adverte que, de mapas, elas passaram a ser obstáculos, interpondo-se entre os humanos e o mundo. Não mais se interpreta o significado dessas imagens como representação de algo exterior, mas se vive em função dessas cenas. Para Flusser (2011), com a atual qualidade técnica das representações do mundo, mais elas são entendidas como as próprias representações, como os fatos em si; os fatos representados já não importam, passando então a bloquear o mundo. Com isso, para Flusser (2013), essa seria uma forma de alienação. Essa alienação ocorre ao passo em que o ser humano se esquece do motivo pelo qual as imagens são criadas, que é o de "servirem de instrumentos para orientá-lo no mundo" (Flusser, 2011, p. 18). A humanidade vive assim, com as imagens sustentando-se a si mesmas: elas são a realidade e representam a realidade. A interação ocorre entre imagens e não mais entre atores sociais.

Uma imagem estampada em uma publicidade turística mostra, em detalhes, os componentes de uma paisagem natural ou cultural. Em um ambiente virtual, é até mesmo possível utilizar essas imagens como componentes de uma visão em $360^{\circ}$ de boa parte do planeta. O turista, ao ter acesso a essa profusão de imagens que representam alguma localidade, facilmente pode tomar as representações como realidade em si. Exemplo disso é o chamado turismo virtual. Conforme observam Ghisi e Macedo (2006), essa não é, propriamente, uma modalidade de turismo reconhecida e definida, porém é inegável a existência de uma atividade virtual que substitui, mesmo que por instantes, a experiência turística de estar presente em alguma outra localidade. É esse tipo de ambiente que faz com que as imagens tomem o lugar do mundo, ao qual pretendem representar. E gigantes da tecnologia fornecem ferramentas cada vez mais inovadoras para a imersão virtual de alguém interessado em viajar.

A publicidade turística se desenvolve praticamente toda em imagens. Há, de certo, a imaginação turística, através da literatura e da música, no entanto, a publicidade turística massificada ocorre através das imagens. É através das imagens publicitárias que uma paisagem surge como um produto a ser adquirido e consumido por determinado público. As empresas turísticas e prestadores de serviços, envolvidos em uma viagem, investem em publicidade turística, motivados pelo fluxo de receitas desprendido nessa atividade econômica. O que parece ser vendido pela publicidade são as praias, as montanhas, a gastronomia. As imagens, veiculadas pelos meios publicitários, enfatizam vigorosamente os aspectos naturais e culturais de um destino, evocando a sensação de presença daquela paisagem.

Nesse sentido, a publicidade está envolta, também, na criação de imagens que sintetizem um ideal. A publicidade turística abusa de imagens estereotipadas e, por vezes, irreal de localidades e comunidades. 
Nessa etapa de produção de imagens, a publicidade turística esvazia completamente os significados sociais e históricos, bem como as relações que ocorrem até que um turista, por fim, chegue a determinado destino. As imagens turísticas enganam o consumidor, escondendo dele uma série de informações importantes que deveriam ser analisadas se a tônica da relação fosse de confiança como, por exemplo, as relações sociais que ocorrem durante a prestação de algum serviço, os conflitos cotidianos da localidade representada ou, até mesmo, a existência de alguma crise humanitária.

As imagens turísticas, então, não guiam o ser humano no mundo. Segundo Flusser (2011), elas bloqueiam a visão do mundo, elas se interpõem entre os fatos e o observador turista. Mas a imagem turística é uma imagem produzida por aparelhos. Por ser muito dependente da fotografia, a publicidade turística é marcada pela predominância das imagens técnicas. Esse tipo de imagem, segundo Flusser (2013), programa o observador a reduzir ao mínimo sua visão crítica. Analisa-se, a seguir, como isso ocorre.

\section{A Imagem Técnica no Turismo como Determinador da Atividade}

A publicidade turística faz uso demasiado de imagens que, na atualidade, significa o uso de imagens técnicas. De acordo com Flusser (2011), essas imagens são resultantes da técnica, de um texto científico, diferentemente das imagens tradicionais. Esse conceito exige um detalhamento maior para que se possam compreender as diferenças. Para o autor, "os novos tipos de imagens são mais bem denominados de 'tecnoimagens', e a convenção em que estão baseados é mais bem designada de 'tecnoimaginação' [...]” (Flusser, 2013, p. 146). A técnica é, assim, um produto de textos. Nesse sentido:

"Historicamente, as imagens tradicionais precedem os textos, por milhares de anos, e as imagens técnicas sucedem aos textos altamente evoluídos. Ontologicamente, a imagem tradicional é abstração de primeiro grau: abstrai duas dimensões do fenômeno concreto; a imagem técnica é abstração de terceiro grau: abstrai uma das dimensões da imagem tradicional para resultar em textos (abstração de segundo grau); depois, reconstituem a dimensão abstraída, a fim de resultar novamente em imagem. Historicamente, as imagens tradicionais são pré-históricas; as imagens técnicas são pós-históricas. Ontologicamente, as imagens tradicionais imaginam o mundo; as imagens técnicas imaginam textos que concebem imagens que imaginam o mundo" (Flusser, 2011, pp. 23-24).

As imagens tradicionais são uma representação de mundo, são símbolos. Há um agente imprimindo no meio uma mensagem. Ou seja, abstraem o fenômeno representado na ordem de um grau. Com o texto e a escrita, o agente humano aumenta um grau na representação dos fenômenos - representa o fato através de conceitos que significam ideias. Esses conceitos, que significam ideias, formam uma imagem mental e uma outra representação do mundo. Assim, a imagem técnica advém diretamente dessa predominância da conceituação abstrata. Ao ser um produto de textos, ela aumenta mais um grau na escala de abstração, em relação ao fenômeno retratado. Porém, o realismo técnico dessa imagem se confunde com o realismo do fenômeno em si. A imagem técnica aparece como uma representação fiel e sem margem para dúvidas de um fenômeno, pois ela é resultado de texto científico aplicado (Flusser, 2011).

Wulf (2013) aborda a imagem técnica no mesmo sentido. Ele afirma que as imagens eletrônicas miniaturizam o mundo e o transformam em imagem, sendo isso o oposto da imagem tradicional. Imagem técnica e imagem virtual são, assim, sinônimos, pois uma representação virtual e eletrônica passa, necessariamente, pelo texto científico que concebeu o aparelho que formou aquela imagem. Esse é o processo de alienação que emana da imagem e inunda a visão do observador. Wulf (2013, p. 33) afirma que, com isso "[...] as imagens estão se tornando cada vez mais parecidas, embora diferentes em seu contexto. Elas varrem os espectadores para longe, [...] intimidam. Elas dissolvem as relações entre pessoas e coisas [...] transportam para um mundo de aparências". Porém, é necessário amalgamar esse processo de alienação com o próprio desenvolvimento das tecnologias dos aparatos de imagem. Crary (2012) expõe que o processo de envolvimento do observador com essas imagens técnicas, que a atual alienação do observador em relação 
ao verdadeiro significado das imagens, só foi possível devido a um processo concomitante de ensino e aprendizagem. O espectador foi moldado às imagens. "Nunca houve e nunca haverá um observador que apreenda o mundo em uma evidência transparente. Em vez disso, há diferentes arranjos de forças, menos ou mais poderosas, a partir dos quais as capacidades de um observador se tornam possíveis" (Crary, 2012, p. 16). Desta forma, as imagens técnicas inundam o mundo, hoje, porque ensinaram o observador a observálas, retirando o componente crítico dessa relação.

Nesse mesmo sentido, Belting (2007, p. 54) escreve que "ya desde épocas muy tempranas el deseo de reproducciones auténticas fue satisfecho medianteprocedimientos tecnológicos anónimos que excluyen la imitación bumana y que eliminan la intervención humana [...] ${ }^{[3]}$ ". O observador foi moldado a não interferir na representação que a imagem traz como acontece com as imagens tradicionais, obtendo uma garantia técnica de semelhança. Belting (2007) afirma que a confiabilidade das imagens tradicionais, que reside mais na fé, se desenvolveu para a invenção de técnicas de imagem que diminuem o risco de equívocos. Desta forma, "a função das imagens técnicas é a de emancipar a sociedade da necessidade de pensar conceitualmente. [...] Substituir a capacidade conceitual por capacidade imaginativa de segunda ordem" (Flusser, 2011, p. 27).

O funcionamento da imagem técnica pode ser explicado como uma caixa-preta, em que não se obtém acesso imediato ao processo do aparelho, por demasiada complexidade:

[...] "um tipo de caixa-preta que tem textos como dados inseridos (input) e imagens como resultados (output). Todos os textos fluirão para essa caixa (notícias e comentários teóricos sobre acontecimentos, papers científicos, poesia, especulações filosóficas) e sairão como imagens (filmes, programas de TV, fotografias). O que quer dizer que a história fluirá para dentro daquela caixa e sairá de lá em forma de mito e magia" (Flusser, 2013, p. 146).

A fotografia, desta forma, é o pontapé inicial desse processo da imagem técnica. $\mathrm{E}$ a fotografia só pode se desenvolver porque, anteriormente, as técnicas e as experimentações científicas, a respeito da visão e percepção imagética, foram ensinando os observadores a observá-las, através do uso de taumatrópios, fenacistoscópios, a descoberta da perspectiva e a invenção da câmara escura (Crary, 2012). Esses aparelhos foram frutos de trabalhos científicos a respeito da visão e da imagem e os produtos, advindos desses aparelhos, podem ser considerados pré-imagens técnicas. A fotografia é a primeira imagem técnica (Flusser, 2011), pois conseguiu retirar o componente humano existente nas outras experimentações, que não produziam representações fiéis dos fatos representados.

Com isso, é possível salientar que o mundo da publicidade turística é o da imagem técnica. Para evocar a ausência de uma localidade através de uma imagem técnica, a imagem publicitária de um destino turístico reforça os componentes estéticos, manipula a visão do observador, induz à aceitação daquela visão como realidade fiel. Isso acontece por meio de fotografias, de filmes, vídeos em internet. Assim, Wulf (2013) afirma que a profusão de imagens, na verdade, turva o vínculo entre elas e a realidade. As imagens têm a si mesmas como referência e não mais um fenômeno externo e concreto, se transformando em simples jogo de aparências, hipertrofiando a visão. Torna-se difícil distinguir entre a vida em si, a fantasia e a realidade.

Dados apresentados pela UNWTO (2018) expõem que, somente em 2017, as receitas brutas geradas com turismo internacional ficaram em U\$ 1.220.000.000.000,00 (um trilhão e duzentos e vinte bilhões de dólares), o que representa 10\% do Produto Interno Bruto mundial. Em 2016, 1,2 milhões de pessoas realizaram viagens turísticas internacionais e a estimativa para 2030 é de que se alcance a margem de 1,8 bilhões (UNWTO, 2018). Sem a imagem técnica veiculada pela publicidade turística, essas estatísticas seriam outras, uma vez que as imagens técnicas "despertam desejo, elas fascinam e prendem, reduzindo limites e diferenças. Ao mesmo tempo, elas escapam ao desejo; ainda que presentes elas se referem e apontam ao ausente" (Wulf, 2013, p. 34). Sem esse despertar do desejo, a atividade turística não seria capaz de movimentar um contingente tão grandioso de pessoas. 


\section{Instagram e o Mundo das Imagens Técnicas}

A imagem técnica se propaga em diversos meios. Belting (2007) salienta que, devido à melhoria da técnica, que se expandiu e se descontinuou para algo não transparente, sendo mais discreta, a imagem técnica é também a imagem digital. "El mundo virtual [...] niega la analogía con el mundo empírico, y ofrece impresiones transcorporales a la imaginacion [...] ${ }^{[4]}$ "(Belting, 2007, p. 50). O mundo virtual se configura, assim, como um dos principais meios de propagação da imagem técnica no turismo. Nesse sentido, analisar o ambiente virtual e sua relação com o turismo torna-se imprescindível. Por ser a imagem técnica o foco, o ambiente virtual mais propício para investigação é o Instagram, uma rede social baseada na utilização de fotografias.

O Instagram é um aplicativo para smartphones que permite a seu usuário publicar fotografias e vídeos, aplicando alguns filtros de edição de imagem, sendo também uma rede social, em que os usuários podem interagir com comentários, conversas privativas, entre outras formas. É baseado exclusivamente em conteúdo imagético, sendo a principal rede social nesse formato. De acordo com notícia veiculada pelo site Terra. (2012, abril 18), o Instagram foi comprado pelo Facebook, no ano de 2012, em uma operação que custou U\$ 1.000.000,00 (um milhão de dólares) aos cofres da empresa de Mark Zuckerberg. Tal informação é significativa para que se possa entender o caráter comercial que o aplicativo desenvolve atualmente. Por ser um aplicativo gratuito e sem a publicidade agressiva, como ocorre no Facebook, as cifras da compra revelam o interesse no potencial de capitalizar que o Instagram demonstra ter. Conforme relata Rodríguez, A. (2017, outubro 5), em reportagem veiculada pelo jornal espanhol El País, o número de usuários é de 1,2 bilhões de pessoas. Por ter um grande número de usuários a nível mundial, o aplicativo tornou-se um novo vetor para a publicidade. Segundo uma reportagem de Bargueño, M. Á. (2017, abril 18, s/p), "marcas de todo tipo viram o potencial dessa audiência e estão pagando a eles uma grana boa para promover sutilmente seus produtos nessa rede social". Porém, devido ao passado não comercial do aplicativo, há a predominância das interações sociais espontâneas com aversão à publicidade tradicional, sendo devido a isso que as empresas buscam veicular anúncios de formas mais sutis.

As fotografias publicadas no Instagram, em muitos casos, são completamente editadas previamente. Quando há a publicação de uma imagem sem nenhuma modificação, os usuários costumam utilizar hashtags, ou seja, uma ferramenta que inclui a imagem em uma rede de busca dentro do próprio aplicativo, que enfatizem esse aspecto, como a \#nofilter. As imagens de Instagram propiciam ângulos diferentes para lugares já conhecidos, mostram composições gastronômicas belas e elaboradas, evidenciam a parte considerada mais atraente das pessoas e animais. As imagens publicadas no aplicativo carregam elevada carga estética e muita melhoria tecnológica. Assim, o aplicativo promove a utilização da imagem como um fim em si mesma. Elas não mais representam um fenômeno do mundo, elas são editadas para que se pareçam como o mundo em si. É esse o caráter da imagem técnica, de acordo com Flusser (2011).

As imagens de destinos turísticos publicadas pelos usuários mais famosos e com mais seguidores se alastram para outras redes sociais e ficam em evidência. Esses usuários que reúnem grande número de seguidores são classificados pelo aplicativo com uma escala que vai de $\mathrm{C}$ a $\mathrm{A}++$, segundo informações obtidas pelo site Social Blade (2018), especialista em métricas e estatísticas de redes sociais. Quanto mais próxima à classificação A, maior é a audiência que aquele usuário movimenta, gerando comentários e outras interações sociais e econômicas que extrapolam a esfera virtual.

Os usuários famosos cultivam uma audiência e o que eles oferecem, quando veiculam publicidade, é exatamente essa audiência para determinada marca ou produto. Assim, é possível verificar o que é analisado por Smythe (1977), que considera que os meios de comunicação têm como mercadoria não uma mensagem, uma informação, imagem, entretenimento, mas sim uma audiência, um público. Smythe (1977) considera que os meios de comunicação em massa criam audiências com especificidades previsíveis e as induzem através de notícias e entretenimento feitos para manter a atenção dessa audiência específica, consequentemente, dirigindo a uma resposta favorável aos produtos que são anunciados por essas comunicações. Essa audiência 
possibilita que a publicidade atinja possíveis consumidores, otimizando o poder publicitário que é respaldado por figuras públicas que gozem de certa credibilidade perante seu público específico.

\section{Procedimentos Metodológicos}

Por meio de uma abordagem crítica, a metodologia desse estudo é pautada em pesquisa bibliográfica, compondo uma breve síntese específica de material sobre teorias da imagem advindas do campo da comunicação, com ênfase nos estudos de Belting, Flusser e Wulf. Os autores foram selecionados levando em consideração o impacto de suas obras nos estudos em imagem e, por essa razão, os trabalhos específicos sobre imagem e turismo foram utilizados em menor escala, uma vez que eles abordam a imagem em uma perspectiva ligada ao marketing e à administração.

Esse artigo se configura, também, como uma pesquisa documental. Segundo Gil (2011, p. 147), a pesquisa documental considera "[...] não apenas os escritos utilizados para esclarecer determinada coisa, mas qualquer objeto que possa contribuir para a investigação de determinado fato ou fenômeno”. Desta forma, esse tipo de pesquisa, tradicionalmente, utiliza registros cursivos, entre eles os meios de comunicação de massa, como os jornais e revistas, porém não se limitando a eles (Gil, 2011).

Complementarmente, essa é uma pesquisa exploratória, pois, para Gil (2011, p. 27), visa “[...] a formulação de problemas mais precisos ou hipóteses pesquisáveis para estudos posteriores. [...] Habitualmente envolvem levantamento bibliográfico e documental [...]". Devido a pouca abordagem da teoria da imagem, advinda do campo da comunicação em estudos de turismo, torna-se claro a necessidade de levantar hipóteses que possam ser objeto de pesquisas futuras. Além disso, são “[...] desenvolvidas com o objetivo de proporcionar visão geral, de tipo aproximativo, acerca de determinado fato. [...] é realizado quando o tema escolhido é pouco explorado [...]" (Gil, 2011, p. 27).

Delimitar uma área de estudo como uma rede social, de caráter virtual e estabelecida na internet, requer algumas observações. Conforme Fragoso, Recuero e Amaral (2011), selecionar uma amostragem de pesquisa em internet é uma ação que esbarra em dificuldades como a escala dos dados, a heterogeneidade e o dinamismo dos elementos. Outras dificuldades incluem a representatividade das amostras e seus limites razoáveis. Por ser global, a internet representa um emaranhado complexo de relações advindas de círculos sociais e culturais diversos. Busca-se, aqui, realizar um recorte amostral que exponha elementos significativos para o aprofundamento do campo teórico sobre a relação entre imagem e turismo. Assim, escrevem Fragoso, Recuero e Amaral (2011, p. 67) que "o número de componentes da amostra é menos importante que sua relevância para o problema de pesquisa, de modo que os elementos da amostra passam a ser selecionados deliberadamente, conforme apresentam características necessárias [...]”. Com isso, intencionalmente, se utilizará do Instagram por ser possível, com essa rede social, obter mais claramente os componentes de interesse da pesquisa, que se centra na utilização das imagens para o turismo.

Colocam-se em análise, aqui, dois usuários com grande número de seguidores e que realizam uma publicidade turística sutil: Jack Morris e seu perfil @doyoutravel e, sua namorada, Lauren Bullen com seu perfil@gyspea_lust. Jack Morris é um inglês que, no Instagram, é responsável pelo perfil, de acesso público e ilimitado, chamado @doyoutravel. Este conta, atualmente, com 2 milhões e 700 mil seguidores, sendo classificado como usuário B+, de acordo com o Social Blade (2018). É o maior perfil no âmbito dos usuários que publicam fotos e anúncios de viagens. Além disso, Morris também publica suas imagens de Instagram em um site próprio, o www.doyoutravelphoto.com (Morris, 2018), onde fornece abertamente mais detalhes sobre suas fotos, viagens, trabalhos publicitários e vende pacotes de filtros de edição de imagens para programas como photoshop e similares que possibilitam aos compradores replicar os efeitos utilizados nas postagens de Instagram,o que Morris chama de exclusive@doyoutravel presets.

Segundo Bargueño (2017), Morris publica cerca de nove fotos por mês e não faz nenhuma publicidade por menos de 3 mil dólares. Ele e a namorada australiana Lauren Bullen, responsável pelo perfil @gyspea_lust, 
com 2 milhões e 100 mil seguidores, viajam pelo mundo realizando esse trabalho publicitário. A maioria de suas publicações de Instagram veicula publicidade de empresas do setor do turismo, mas é possível encontrar também publicidade de empresas de moda e de produtos de beleza. Colocá-los em análise, de acordo com Fragoso, Recuero e Amaral (2011), permite obter compreensão holística do fenômeno pesquisado, a publicidade em turismo, que ocorre, geralmente, dispersada em vários perfis de usuários dessa rede social.

As imagens analisadas foram selecionadas, tendo em vista o conteúdo imagético e as informações passadas pela legenda, de forma a possibilitar a relação entre a cena retratada na imagem e a ação publicitária envolvida na publicação, seja de maneira explícita ou sugerida através de marcações de outros perfis e pelo uso de hashtags. A coleta de imagens ocorreu entre os anos de 2018 e começo de 2019. Em conjunto, o casal apresenta cerca de 2400 imagens publicadas, sendo necessário, então, selecionar imagens que demonstrassem o padrão de atuação, sem que fosse preciso quantificar em relação ao total, na perspectiva apresentada por Fragoso, Recuero e Amaral (2011).

\section{ANÁLISE E Discussão}

A audiência total do casal Morris e Bullen abrange mais de 4 milhões de usuários. Essa audiência amplifica sobremaneira as mensagens passadas nas publicações e oferece uma vitrine poderosa para as marcas que os contratam. Nessa perspectiva:

[...] "quem vê suas fotos gostaria de ser tão atraente como Jack ou Lauren e estar onde eles estão. As marcas chegaram à mesma conclusão e acrescentaram uma linha à equação: quem os vê gostaria de estar no mesmo hotel ou usar o mesmo relógio" Bargueño, M. Á. (2017, abril 18, s/p).

Assim, a publicidade turística é responsável por mantê-los sempre em viagem, fomentando em outros usuários o desejo de estar no mesmo local. Aliadas a isso, as fotos publicadas por Morris e por Bullen são sempre muito bem produzidas tecnicamente, com alterações sutis em cores e luminosidade e recheadas de elementos simbólicos evocando uma experiência fantástica. É o caso da Figura 1:

Figura 1: Morris in a "Just a regular morning in Kenya", 2017

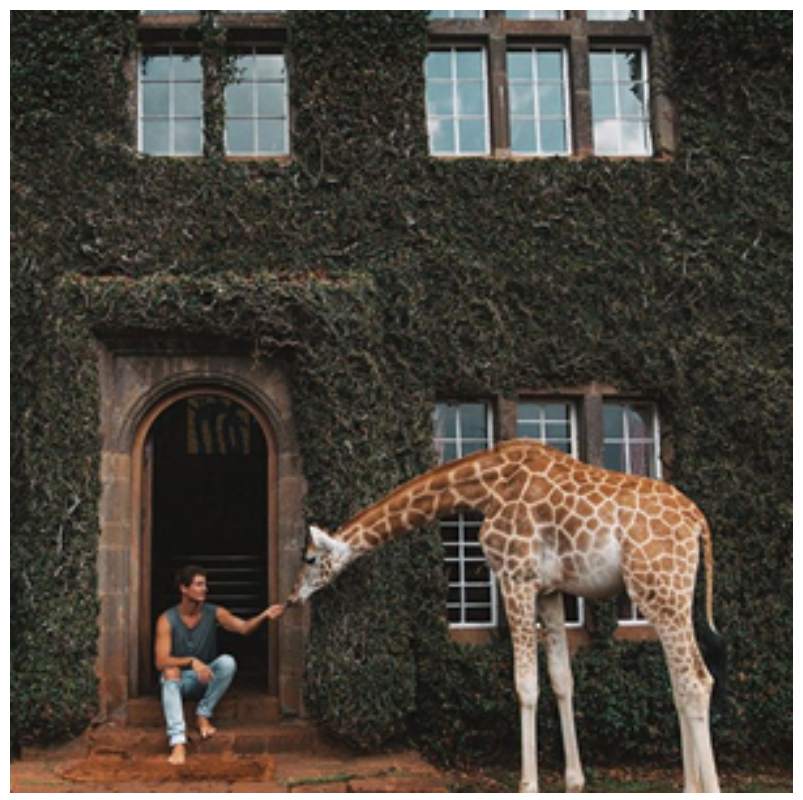

FIGURA 1

Morris in a Just a regular morning in Kenya 2017

Fonte: @doyoutravel (foto publicada em 5 de abril de 2017) 
Essa imagem, aparentemente, não há apelo publicitário na publicação, apenas apelo turístico, carregado de estética, o que revela o caráter publicitário escondido na imagem. A imagem traz um elemento exótico, retratando uma visita ao Quênia. Entretanto, analisando essa publicação com outras que a antecedem, descobre-se que Morris esteve no país hospedado em uma rede de hotéis de luxo, que mistura safári com hospedagem. A Figura 1 foi tirada dentro de um desses hotéis de luxo e forma uma representação maior do Quênia como um lugar onde é possível ter contato com animais selvagens cotidianamente e sem perigo.

A sequência de imagens publicadas, por Morris, revela uma preocupação estética coesa, em que prevalecem sempre os mesmos tons de cores e efeitos de iluminação, garantindo que não ocorram discrepâncias nas representações veiculadas por ele, buscando, assim, diminuir a criticidade do observador, no sentido apontado por Flusser (2011), objetivo das imagens técnicas. A coleção de imagens que retratam essa viagem faz o mesmo tipo de representação do Quênia, prevalecendo os componentes selvagens e até mesmo étnicos da paisagem, conforme mostra a Figura $2^{[5]}$ :

Figura 2: Morris “As proud members of the @livelokai circle”, 2017

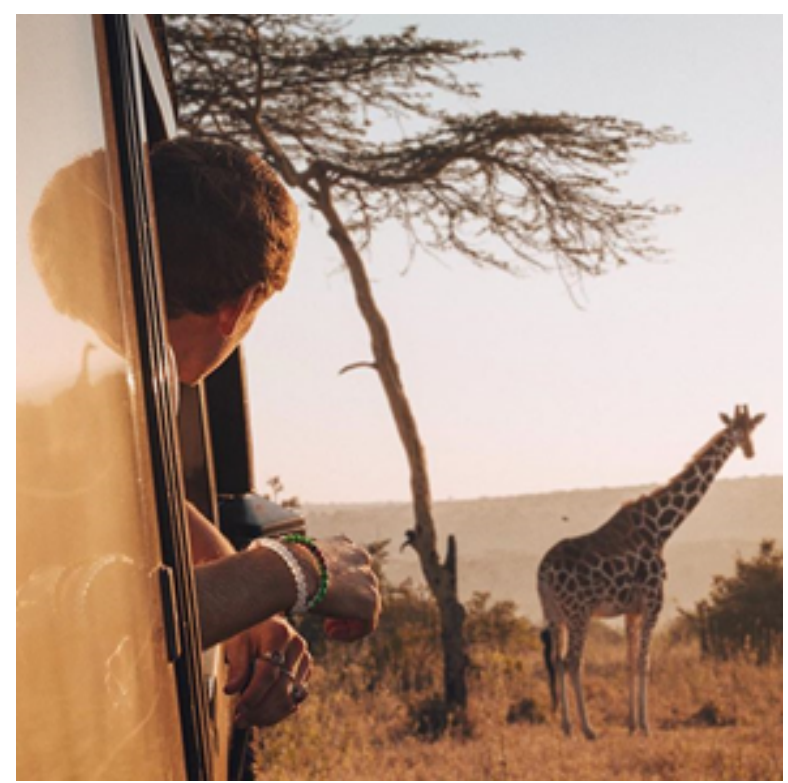

FIGURA 2

Morris As proud members of the @livelokai circle 2017

Fonte: @doyoutravel (foto publicada em 1 de junho de 2017)

Novamente, o exótico tem espaço na composição fotográfica de Morris. Essa publicação faz referências diretas a algumas empresas, entre elas o site Trip Advisor, um portal virtual que avalia lugares turísticos, restaurantes, hotéis, atrações turísticas e que também permite a busca e venda de passagens aéreas e hotéis. Em um texto engajado com a situação de refugiados africanos, Morris cita o envolvimento dele e da namorada com a campanha de apoio a esses refugiados encabeçados pelo Trip Advisor. Esse portal é um dos principais entre viajantes de todo o mundo em busca de informações e referências a respeito da qualidade das empresas turísticas. Assim, é possível entender que a viagem de Morris e Bullen ao país africano envolveu uma série de empresas que investiram em publicidade sutil nas publicações envolvendo o casal. Há, no texto de publicação, a menção a uma organização humanitária, @TheIRC, que lida com a situação de refugiados, porém, não se vê nenhum elemento que faça referência à essa questão. O que se evidencia é a publicidade do fórum de viagens e de uma marca de acessórios de vestimenta, @livelokai; Morris aparece na fotografia utilizando uma pulseira da marca. O que move os usuários que permitem publicidade e que são vetores da publicidade não são questões maiores e mais ligadas às realidades de cada país visitado. 
Em outra publicação (Figura 3), dessa vez em outro país, os elementos se repetem. Há o componente mágico, há a representação de mundo por semelhança, há a publicidade turística disfarçada e há a falta de ligação com qualquer situação mais ligada aos fatos do país:

Figura 3: Morris, “A hot tub in the middle of a snowy forest @northernlightsranch”, 2018

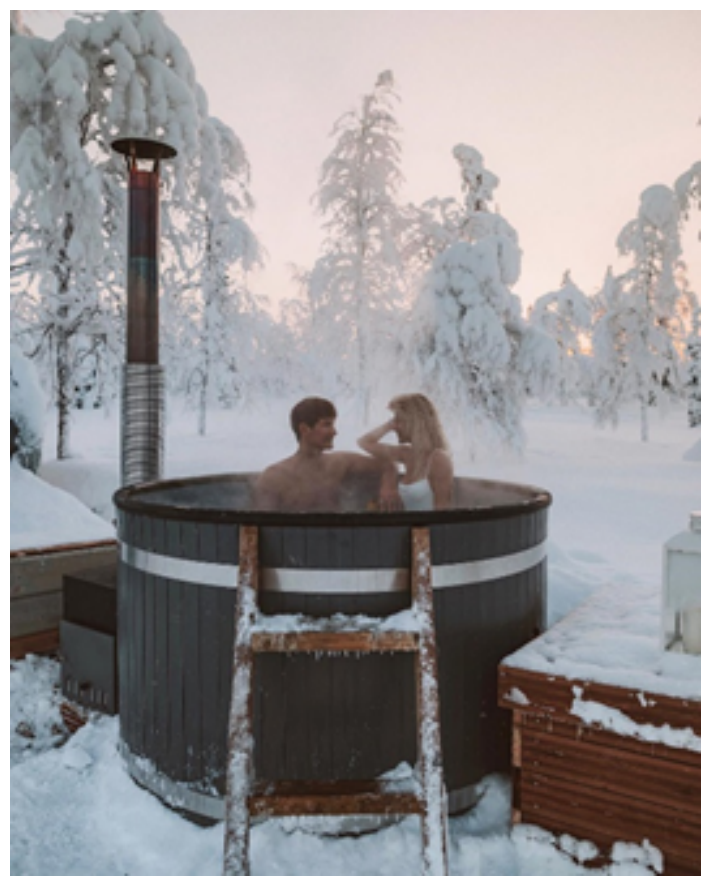

FIGURA 3

Morris A hot tub in the middle of a snowy forest @northernlightsranch 2018

Fonte: @douyoutravel (Foto publicada em 7 de fevereiro de 2018)

A imagem retrata uma viagem que Morris e Bullen fizeram pela Lapônia, na Finlândia. A publicidade é de um hotel de luxo em meio a floresta. Não há menção explícita da marca na imagem e a legenda também não é uma publicidade tradicional pois insere a empresa patrocinadora de maneira informal, quase ao acaso. A situação é sugerida, a publicidade turística, nessa imagem, seduz o público de Morris a realizar a mesma experimentação e, consequentemente, se hospedar no mesmo hotel que oferece os equipamentos utilizados pelo casal.

Por fim, na Figura 4 exposta abaixo, é possível perceber como Lauren Bullen utiliza as mesmas técnicas de fotografia e manipulação de imagem para realizar o mesmo tipo de publicidade que seu namorado:

Figura 4: Bullen, “Nightfall @conradboraboranui \#conradboraboranui \#ad”, 2018 


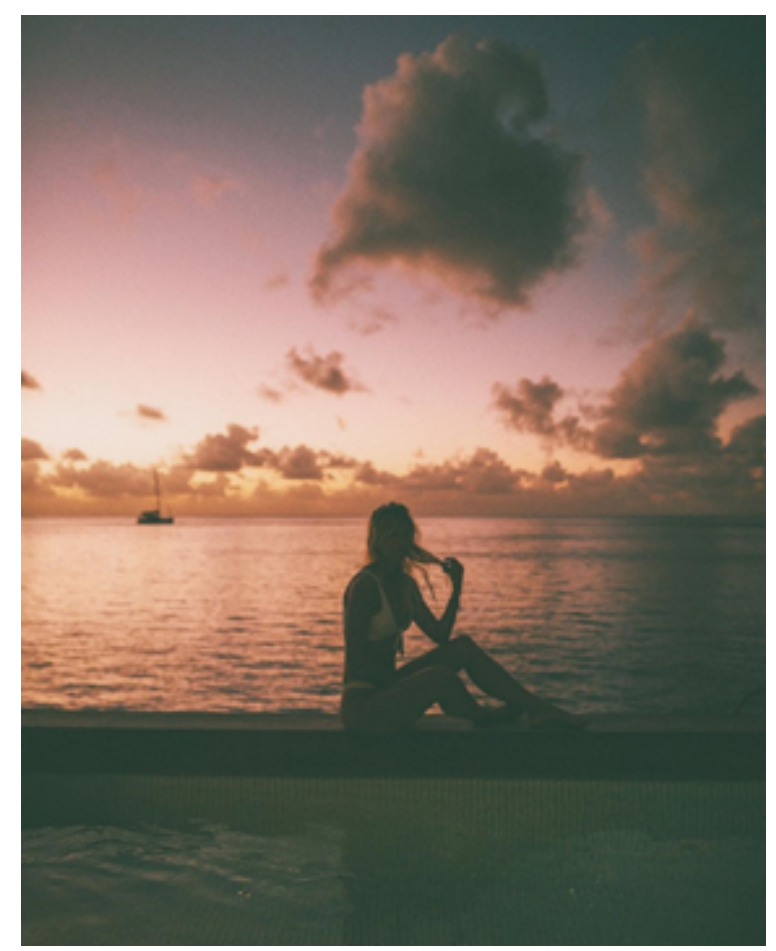

FIGURA 4

Bullen Nightfall @conradboraboranui \#conradboraboranui \#ad 2018

Fonte: @gypsea_lust (Foto publicada em 14 de agosto de 2018)

Essa publicação é uma passagem do casal Bullen e Morris por Bora Bora, na Polinésia Francesa. A legenda da imagem deixa claro que é uma publicidade, especificamente pelo uso da \#ad, que significa advertisement, ou seja, publicidade. A marca promovida é a rede de hotéis de luxo Conrad. No centro da imagem, Bullen repousa nas dependências do hotel, ao cair da noite. A fotografia busca transmitir tranquilidade, com o mar sereno e uma silhueta de barco navegando idilicamente ao fundo. As cores do pôr do sol são retocadas, criando um efeito de sombra na figura de Bullen. Com isso, a autora da foto procura aproximar todos esses conceitos em características existentes no hotel em questão. Mesmo sem mostrar claramente as empresas anunciadas, as imagens de Morris e Bullen cumprem com a função publicitária. Devido ao número expressivo de seguidores que cada um apresenta, o impacto que essas imagens causam é extenso, influenciando muitos outros usuários viajantes menos famosos a alinhar-se ao estilo do casal.

O caso de Jack Morris e Lauren Bullen é expressivo, pois reúne todos os elementos da utilização de imagens técnicas para propagar destinos turísticos e empresas que exploram esse mercado. O Instagram é, nesse sentido, o mundo das imagens técnicas, pois fornece ao observador e consumidor dessas imagens uma reprodução de mundo e constrói, em si, o próprio mundo. No que se refere ao turismo, o Instagram fomenta que cada usuário propague sua versão das localidades, a sua realidade, o seu entendimento de mundo. Os usuários constroem sua versão dos fenômenos, aplicam seus próprios conceitos ao material que publicam, passando a depender dessas imagens para viver a realidade. Flusser sintetiza: "os novos meios, da maneira como funcionam hoje, transformam as imagens em verdadeiros modelos de comportamento e fazem dos homens meros objetos" (Flusser, 2013, p. 159). O Instagram, nesse contexto, manipula a percepção de realidade dos observadores e cada usuário tem seus modelos de comportamento, afastando-se cada vez mais da experiência concreta para encontrar significado em imagens vazias, frutos da técnica científica. É nesse sentido que Baudrillard (1991) afirma que todas as formas atuais de atividades tendem para uma forma publicitária, ou seja, um modo operacional simples e sedutor, simulando mensagens publicitárias mesmo quando não são. O Instagram demonstra esse aspecto com muita precisão. 
Nesse cenário, usuários como Morris e Bullen não são exclusividade, são modelos de vida. A representação de mundo que constroem contribui para o estranhamento, para o afastamento do entendimento do motivo das imagens existirem, conforme explica Flusser (2013). Não há indícios de que eles se envolvam com a realidade que estão visitando, uma vez que sempre estão hospedados em meios de hospedagem luxuosos, resorts, locais normalmente ligados à separação entre o empreendimento e comunidade local. Quando existem outros personagens nas imagens, essas pessoas são sempre badulaques estéticos, mostrando um evidente afastamento.

Não se quer, porém, exigir que todos os usuários publiquem fotos de viagens em que se envolvem com os problemas locais, mas sim chamar a atenção para a função de biombo que essas publicações e essa produção de imagens passam a exercer. A imagem técnica engana o olhar humano justamente pela sua semelhança, levando a uma idealização da realidade que deveria retratar.

\section{Considerações Finais}

O Instagram é uma rede social que nasceu centrada na imagem. As empresas detectaram nessa comunidade mundial de usuários um mercado em potencial e passaram a investir recursos em usuários com grande número de seguidores, influenciando os gostos e desejos de forma insidiosa, não mais centrada em campanhas tradicionais de publicidade e sim pulverizando suas mensagens em vários perfis com grandes audiências. Para as empresas, essa estratégia se apresenta como uma alternativa de corte de custos em relação à publicidade tradicional, uma vez que veicular seus produtos e serviços através de influenciadores custa muito menos, como expôs Bargueño, M. Á. (2017, abril 18), ao relatar que Morris aceita campanhas publicitárias que paguem a partir de três mil dólares e atinge um público muito maior.

Assim é que, com as novas formas de propagação publicitária, escondidas em imagens a princípio pessoais de usuários de redes sociais, a experiência evocada pelos seus realizadores é irrealizável fora daquele espaço, considerando que as imagens por eles publicadas passam por muitas camadas de manipulação e retoques. Para o turismo, uma imagem cheia de melhorias técnicas que represente um destino turístico é uma realidade completamente inacessível a um turista que foi até o local da imagem vista no Instagram. Os desejos fomentados por essa publicidade não se tornam realidade nunca, apenas simulam.

Não encontrando as mesmas cores e a mesma atmosfera vista em fotos que circulam por Instagram e outras redes sociais, os turistas que são motivados por essas imagens retratam o lugar com seus próprios desejos, manipulando, igualmente as imagens que produzem e que depois propagam. Porém, com um agravante: eles precisam de algo que os façam crer que conseguiram viver a experiência desejada. A presença na localidade turística já não basta para nutrir a sensação de ter estado na localidade turística, mas sim a imagem fotográfica adquirida lá.

Nessa perspectiva, as imagens compartilhadas pelo Instagram são o vetor ideal para a publicidade. Cada usuário é uma agência de publicidade turística ambulante e voluntária. A utilização do aplicativo é, muitas vezes, recreacional. Com a sedução de ganhos financeiros, os usuários com grande número de seguidores buscam deliberadamente esse caráter comercial advindo da publicidade paga, afinal, quem não gostaria de viajar ganhando para isso e publicar imagens que retratem seu modo de ver as localidades? No caso de Morris e Bullen, a forma publicitária está impregnada em suas fotografias, enfraquecendo a mensagem que buscam transmitir. Sem as legendas que acompanham as fotos, torna-se difícil saber quais são publicidades pagas e quais não, fazendo com que seus seguidores interpretem tudo como publicidade.

No Instagram, todas as imagens tendem para a publicidade e esgotam-se aí. Um turista que, motivado pelas imagens vistas no aplicativo, fotografa sua viagem e publica seu álbum nos meios virtuais, busca tanto ter para si e para outros uma prova de que esteve em tais lugares, como também busca perpetuar seu "olhar", impactando outros, pois a forma publicitária está escondida desde o início da viagem. As imagens resultantes da viagem já são publicidade. 
Através das imagens técnicas, as empresas turísticas que movem a publicidade fomentam os mais variados desejos, interessadas tão somente no volume de recursos que a atividade turística movimenta. Os fatos do mundo cotidiano mostram que a escalada da imagem técnica coloca os observadores como dependentes dela para entender o mundo. No caso da publicidade, as imagens técnicas invadem e tomam conta de quase todas as experiências pessoais, como as viagens, e aprisionam os observadores dessas imagens em mundos virtuais idealizados. Esse fenômeno é visível no Instagram e deixa claro que o objetivo final é a capitalização de toda e qualquer vivência humana, impossibilitando o contato com a realidade sem ser através de um filtro econômico e comercial.

\section{REFERÊNCIAS}

Bargueño, M. Á. (2017, abril 18). Casal de millenials tem o melhor trabalho do mundo. Recuperado em fevereiro 24, 2018, https://brasil.elpais.com/brasil/2017/04/17/economia/1492426451_975980.html

Belting, H. (2007). Antropología de la Imagen. Buenos Aires: Latingráfica.

Bignami, R. (2002). A Imagem do Brasil no Turismo: construção, desafios e vantagens competitivas. . São Paulo: Aleph. Botton, A. d. (2012). A Arte de Viajar. Rio de Janeiro: Intrínseca.

Bullen, L. (2018, agosto 14). Nightfall @conradboraboranui \#conradboraboranui \#ad. Recuperado em janeiro 08, 2019, https://www.instagram.com/gypsea_lust/

Crary, J. (2012). Técnicas do Observador: visão e modernidade no século XIX. Rio de Janeiro: Contraponto.

Fragoso, S., Recuero, R., \& Amaral, A. (2011). Métodos de Pesquisa Para Internet. Porto Alegre: Sulina.

Ghisi, L., \& Macedo, S. (2006). Turismo virtual on-line: um estudo em sites brasileiros que divugam turismo. III CONVIBRA - Congresso Virtual Brasileiro de Administração. Itajaí: UNIVALI.

Gil, A. C. (2011). Métodos e técnicas de pesquisa social. (6 ed.). São Paulo: Atlas.

Gunn, C. (1972). Vacationscape: designing tourist regions. Washington: Taylor \& Francis.

Jafari, J. (1994). La cientifización del turismo. Estudios y Perspectivas en Turismo, 3 (1), pp. 7-36.

Morris, J. (2018, fevereiro 07). A hot tub in the middle of a snowy forest. Recuperado em fevereiro 24, 2018, https:// www.instagram.com/doyoutravel/

Morris, J. (2017, junho 01). As proud members of the @livelokai circle. Recuperado em fevereiro 24, 2018, https://w ww.instagram.com/doyoutravel/

Morris, J. (2018). Do You Travel. Recuperado em fevereiro 24, 2018, http://doyoutravelphoto.com/

Morris, J. (2017, abril 05). Just a regular morning in Kenya. Recuperado em fevereiro 24, 2018 https://www.instagr am.com/doyoutravel/

Rodríguez, A. (2017, outubro 5). Vocêe é mais feliz no Instagram, e sabe disso. Recuperado em fevereiro 25, 2018, https ://brasil.elpais.com./brasil/2017/09/29/tecnologia/1506683537_908860.html

Sartre, J.-P. (2008). A imaginação. Porto Alegre, RS: L\&PM.

Smythe, D. (1977). Communications: blindspot of the western marxism. Canadian Journal of Political and Social Theory, $1(3)$.

Social Blade. (2018). Recuperado em fevereiro 24, 2018, https://socialblade.com/instagram/user/doyoutravel/futur eprojections.

Terra. (2012, abril 18). Negociado por Zuckerberg, preço do Instagram caiu pela metade. Recuperado em fevereiro 24, 2018, https://terra.com.br/noticias/tecnologia/negocios-e-ti/negociado-por-zuckerberg-preco-do-instagram-c aiu-pela-metade,3d9afe32cdbda310VgnCLD200000bbcceb0aRCRD.html 


\section{Notas}

[1] Artigo resultante de dissertação de mestrado em Comunicação pela UEL - Universidade Estadual de Londrina, concluído no ano de 2019.

[2] "os homens e as mulheres se isolam dentro de sua atividade visual, que estabelece as delineações da vida, aquela unida simbolicamente ao que chamamos de imagem” (Belting, 2007, p. 14, tradução nossa).

[3] "já desde muito cedo, o desejo por reproduções autênticas foi satisfeito com procedimentos tecnológicos anônimos que excluem a imitação humana e que eliminam a intervenção humana” (Belting, 2007, p. 54, tradução nossa).

[4] "O mundo virtual [...] nega a analogia com o mundo empírico e oferece impressões transcorporais à imaginação" (Belting, 2007, p. 50; tradução nossa).

[5] Texto de descrição da foto na publicação:“As proud members of the @livelokai circle, @gypsea_lust and I traveled to Nairobi, Kenya to take part in a curated Balanced Trip as part of the \#WearYourWorld campaign in partnership with @TripAdvisor and @theIRC. Our journey was a series of highs and lows, shedding some light on the refugees whose lives have been shattered by conflict and disaster. Through travel, we learn that we are all citizens of the same world. \#livelokai" (Morris, 2017). 